\title{
AN OVERVIEW OF TOTAL QUALITY MANAGEMENT APPROACH: AN EVALUATION FOR ABC COMPANY INTEXTILE INDUSTRY
}

\author{
DOI: 10.17261/Pressacademia.2020.1240 \\ PAP- V.11-2020(12)-p.57-61
}

\section{Aysenur Erdil}

Istanbul Medeniyet University, Istanbul, Turkey. runesyalidre@gmail.com,ORCID:0000-0002-6413-7482

\section{To cite this document}

Erdil, A., (2020). An overview of total quality management approach: an evaluation for ABC company in textile industry. PressAcademia Procedia (PAP), V.11, p.57-61

Permemant link to this document: http://doi.org/10.17261/Pressacademia.2020.1240

Copyright: Published by PressAcademia and limited licensed re-use rights only.

\begin{abstract}
Purpose- The purpose of this study, after investigating the key elements and main concepts of Total Quality Management (TQM) through a comprehensive literature research, is to appliy it to a business to fully find out these concepts. This business, which is one of the companies in textile industry in Turkey, is chosen for this destination because its top management is already informed of the advantages of TQM and supports the implementation.

Methodology- Competitive advantage, in the context of business, is a powerful concept, and achieving it should be the ultimate goal of any company. TQM is about continuous performance improvement of individuals, groups and organisations. In today's world, many organisations adopt TQM approach to attain competitive advantage in the market. The organizations achieve a competitive advantage by carefully and constantly analyzing its people's, customers' and suppliers' needs and by organizing and operating to meet these needs the first time and every time Implementation of the TQM process is one of the most complex research that an organization, either private or public, can undertake.

Findings- The analysis reveals that the applications begin with the preparation of some questionnaires for all employeers of the company its people, customers, people working in this firm to find out their satisfaction levels since TQM requires finding the points due to statistical Control where they are dissatisfied with the business and promote the company. The evaluations are analyzed in detail by applying a comprehensive methodology. The findings of the evaluation are declared with the contribution of the management.

Conclusion- This provides to highlight the difference between its expectations and the actual results. At the end of the study, some suggestions for the company are presented depending on the evaluations.
\end{abstract}

Keywords: Analyse, business, textile industry, total quality management (TQM).

JEL Codes: Q56, E32, L10.

\section{INTRODUCTION}

Over the last thirty years the business environment has been changing at an ever increasing rate. This has been caused by a whole series of factors including technological development, globalisation, competition and increasing customer demand to have better quality goods and services. It is being increasingly recognised that high quality products and services and their associated cus tomer satisfaction are the key to survive for any organisation. Quality has become one of the most important consumer decision factors in the selection among competing products and services. It is also the main subject of Quality Control and TQM. Thus, This is necessary to make the implementation according to the subject.

The choice of competitive services and products has made quality one of the most significant aspects for customer perception. Whether the consumer is an individual, an industrial company, a retail organization or a militant defense programme, the phenomenon is widespread. Therefore, understanding and quality improvement is a key factor that leads to success, growth and increased competitiveness. Improved quality and successful use of quality as an integral part of the overall business strategy have significant returns on investment. To consider taking a global perspective and concepts and theories about quality management, it is important to understand the entire monitoring system. Administration (TQM) as 'a new management approach (Wilkinson, 1992; Oakland, 2005). TQM is a connotation that is rooted in the continuous improvement of market results and the consistency of the products generated by these operations; it is also an holistic management process, geographically restored over a organization and which includes both divisions and 
staff and applied retrospectively to cover all vendors and consumers (Ngambi and Nkemkiafu, 2015). Total Quality Management as an administrative technique of a corporation that sets itself firmly by its Quality Assessment To ensure the institute Efficient application of total quality management (TQM) in organizations has become a major wotty for the workers detailed consumers, workers, professionals and profitable institutions who serve directly or indirectly within a company ( Qaiser and Rizwana, 2015).

\section{LITERATURE REVIEW}

\subsection{Background of Quality Management}

Since the Second World War there have been several significant developments after centuries when the principles of quality and quality control have evolved dramatically. Quality management began with simple inspection systems in which a company traditionally employs inspection teams to examine, measure or test products and compare them to a product standard. That will happen to all phases of the development of products including the landscape, research in progress and shipping. The system was based on the inspectors' finding of poor quality products from good quality. This is then dismantled, reworked or sold in lower quality. Several outcomes have been obtained (Jabonski, 1994; Johnson, 1993; Kanji and Asher, 1993; Berry, 1991). Four Ps are essential to supplying consumers with premium goods and services. The following four Ps are: Planning - includes policy development and implementation and Techniques; the creation and product management of effective alliances and services. Performance - including the establishment of a metric system for results - An organization's 'healthy scorecard;' self-assessments, evaluations, feedback and benchmarking. Processes - involves process awareness, implementation, creation and redesign; frameworks for controlling quality; continuing improvements. People- Human resources management; changing culture; coordination; individuals - includes; Development and continuing to learn; communication processes (Oakland, 2005, Oakland, 1993; Ross, 1993). TQM's principal goal is to include a management structure and organizational culture that requires a systemic mechanism of continuous enhancement of company processes which would also increase the standard of services TQM provides (Dedhia, 2005; Samat et al., 2002).

\subsection{Ten precepts for the Management of Total Quality}

While many suggestions for successful implementing changes exist, there is no tried and true way of ensuring a successful experience of change. Although the transition is specific to . company and management, companies that plan to make a shift have several different choices, recognized as Ten Commandments for Change (Keleda, 1996; Powell, 1995; Bounds et al., 1995; Porter and Parker, 1993).

1. The evaluation and the need for modification of the organization: this assessment should comprise the background, operational aspects, the effectiveness of the business as well as its strengths and weaknesses at various levels of the organization.

2. Establish a shared vision and direction: The vision is an effort, in sometimes grandiose terms, to express the desired future business. Strategic objectives should be short and up-to - date and should be equally anxious and powerful.

3. Separate from the past: even though hanging onto certain components of organizational structure, such as the destination, mythologies or culture and history, is also essential to take a close look at what activities and frameworks no longer perform and try to get beyond them

4. Set an urgent feeling. The pioneers of organizational reform will create a sense of urgency by thoroughly explaining the condition and speaking to the company itself continuously. TQM data can be presented to organizational members about customer fulfilment, competitive forces, and the need for satisfaction as a status to understand the need to achieve TQM systems.

5. Respect the effective leadership position of every company without the assistance of members who can be seen as tools to transformation, even for the TQM. Top management supports and promotes a vision of TQM culture, aligns employees with a vision and leads to change

6. Policy sponsorship alignment: Implementors must be able to accept TQM 's focus on communication, synergy and staff involvement from those who are the receptors of change, as key sponsors.

7. Development of capable structures: changing the status quo and developing new ways of organizing, measuring and evaluating progress are essential to any organizational changes. Many realistic solutions such as product tests, seminars and preparation, or vis ual frameworks such as flags, gatherings or going through a team's office room may be used.

8. Communicate, connect individuals and remain honest: efficient leadership from the start of a change effort is critical Every dimension of modification has to be mentioned, outlined and discussed at various managerial levels.

9. Supporting and institutionalizing change: administrators highlight the importance of transition by reinforcing their current behavior, and Senior Management engagement is evident and seen everyday.

\subsection{TQM Advantages and Developments}

Generally, TQM has three main advantages and benefits in terms of enhancing profitability and competence, enhancing business efficiency, and improving customer satisfaction. Improved profitability and competitive performance and competitiveness of companies (for instance market shares, growth, investment revenue) are definitely enhanced by improving product and service quality. Higher costs minimize promotions, repeat sales and greater customer shares provide the gains of better quality facilities. Businesses with advancem ent quality are rentier and quality of the product is increasing faster, which is an important component of business profit growth. A quality distinguishing strategy based on the customer can often not only lead to customer satisfaction but also to an increase in sales volume and 
reduced prices (Powell, 1995; Bounds et al., 1995; Porter and Parker, 1993; Cartin, 1993). The main goal of this research is to use it to an enterprise to find out these important concepts after examining the key elements and conceptual frameworks of TQM through extensive literary studies. This company has been chosen for this destination, since its senior management is already aware of and supports the advantages of TQM. It is one of the companies in textile industries in Turkey. The results of the assessment are stated through the management's commitment.

\section{PRODUCTION FOR APPAREL-TEXTILE INDUSTRY}

Apparel is one of the industries where consequential-significant phases of the generation in the industrialised-technical politically organized bodies of households under a single government have been established much more or fewer parallel to this sourcing of producing. Research and Development is the fundamental of this industy. It bases on developping and producing new products to meet consumer demand and find ways to produce these products. Moreover, the relative frequency via which modern goods are defined has accumulated (so-named fast fashion) and the consuming - using up of garments in the industrialised lands-cities-locations have become larger. The Second important issue is marketing of Products of this business which all activities involve in creating and selling profitable Products.

Figure 1: Process Progression of the Manufacturing of Apparel (ABC Apparel Company)

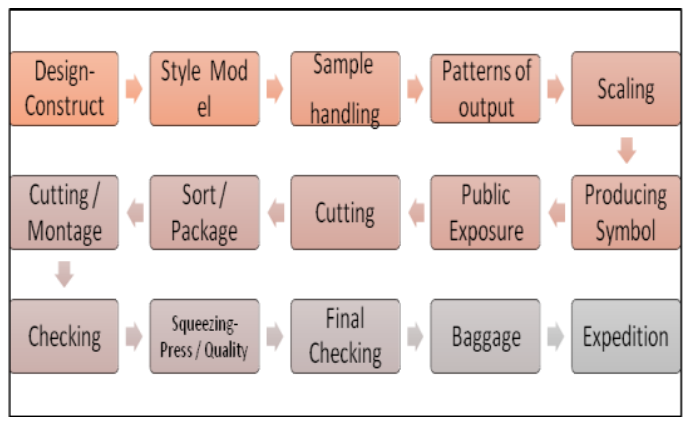

Manufacturers must decide what raw materials to buy and what fabrics to manufacture and they base their decisions on careful studies of what customers want (Macchion et al., 2015; Morgan and Birtwistle, 2009; Martinich, 1997). In a very short time, ABC Company has a vision and can be a leader in the clothing sector of children and teenagers and created a new trademark in Marmara Region. This business consists of design, product management, sampling, human resources, finance, product development, and sales and marketing departments. Process Sequence of Apparel Manufacturing of this company is presented as below in Figure 1 . Apparel production companies have various departments or divisions, and may include - research and merchandising - design and product development.

\section{STRATEGIC PLANNING ON THE APPLICATION OF PRINCIPLES OF TOTAL QUALITY MANAGEMENT}

Leadership or Management of a business is an essential consideration for the performance of an organisation. While successful leadership is not the only component of high performance, it is important to improve it. From total destruction into a powerful and proud organization, effective leadership can transform the organization into effective guidance and supervision. Leadership thus has a powerful effect on an individual's behavior to leverage the capacity for achievement of organizational performance. Leadership has been one of the subjects of growing emphasis in researchers' interest (Esam and Abdul, 2012; Day and Zaccaro, 2007; Juran, 1989). A well-managed quality improvement process (QIP) can help a company achieve that lofty goal and the benefits are real and unbeatable A QIP can provide a company with a sustainable competitive advantage of significant proportions. Some of the benefits to be achieved as below (Juran, 1989; Cartin, 1993; Bound et al., 1995; Garvin, 1998);

-Improving profitability, -Increasing customer retention, -Reducing customer complaints and warrant claims.

-Reducing costs through less waste, rework, and so on, -Greater market sharing, -Increasing employee involvement and satisfaction, lower turnover, -Increasing ability to attract new customers.

The applications tend to plan these questionnaires for all workers, consumers, clients, providers, and workers in this field, as TQM needs the recognition and assistance of points where they are unhappy with industry.

The six topics are seen in the following diagram due to answers of the the questionnaire methodology among many of the subjects falling within each continent.

Region of Opportunities: The subjects in this region are those having an importance score higher than the average and a satisfaction score lower than the average. This means that although people attach an extreme importance to these subjects, ABC Business does not meet their expectations. Therefore, each subject in this region can be seen as an opportunity to increase the satisfaction Level. ABC Business should pay much more attention to these subjects and make some improvements in these fields. These fields are Policies and Strategies, Appreciation and Rewarding, Social Rights and Waging System, Management Attitudes, Working Environment and Prices. 
Region of Strengths: This is the region of subjects that people are satisfied with and give importance to For these subjects, ABC Business seems to meet people's expectations and make them happy. The only thing that must be done is to sustain the current satisfaction level, therefore, there is no urgent need to make improvements. This region has the same fields as the fields of Region of Opportunities.

\section{CONCLUSION}

All people are highly pleased with determining the vision, mission and values altogether as the strategy of the business. One of the subjects that almost all people complain about is that organisational structure, tasks and responsibilities are not clear yet. While workers think that $A B C$ Textile company utilises from their performance effectively, managers and officials do not agree with them. A significant result about social rights and payment system is that the employees of $A B C$ Textile company become unsatisfied with the payment system as educational level increases. In addition, dissatisfaction resulting from working hours and number of working days is directly proportional with the educational level. While employees think the ABC Business utilizes its money effectively, administrators and officials do not agree with them. An essential fact of the civil justice and wage structure is that this company's workers are unsatisfied with the salary program as the standard of employment rises. In fact, the dissatisfaction that results from working hours and the number of working days is directly linked to the degree of employment. People respect your company as you keep pace with technical developments, however the cost of education rises. Another issue that causes discontent for highly educated individuals is the fact that the organisation's context, authority and duties are still unclear. Taking into consideration that the main aim of TQM was to achieve at least a certain degree satisfaction between all employees and to develop and expand this sense of happiness continuously.

\section{REFERENCES}

Berry, T. H. (1991), Managing the Total Quality Transformation, McGraw-Hill, First Edition edition USA.

Bounds, G., Yorks, L., Adams, M. and Ranney, G. (1995). Total Quality Management Toward The Emerging Paradigm, (Mcgraw Hill Series In Management), McGraw-Hill EducationSingapore, 817 p., ISBN-13: 978-0070066786.

Cartin, Thomas, J., Principles and Practices of TOM, ASQC Qualitey Press, Wisconsin, p.14.

Day and Zaccaro, S, J, (2007). Leadership: A critical historical analysis of the influence of leader traits. In Loupes (Ed.) Historical perspectives in industrial and organizational Psychology, 383-405, Mahwah NJ: Lawrence Erbium.

Dedhia, N.S. (2005). Six Sigma Basics. Total Quality Management and Business Excellence, 16 (5), $567-574$. http://dx. doi.org/10.1080/14783360500077468

Esam M. and Abdul, Talib B. (2012) Role of top management leadership and commitment in total quality Management in service organization in Malaysia: A review and conceptual Framework. Elixir Human Resource Management, 51, 11029-11033.

Garvin,D. A. (1998). Managing Quality :The Strategic and Competitive Edge, First Edition, Free Press, New York, 319 pages, ISBN-13: $978-$ 0029113806.

Jabonski, J. R. (1994). Implementing TQM: Competing in the 90s Through Total Quality Management, 2nd Second Edition, Michigan USA, ISBN-13: 978-1878821034, 224 p.

Johnson, R. S. (1993). Management Processes for Quality Operations, Milwaukee, WI:ASQC Quality Press, USA.

Kanji, G.K. and Asher,M. (1993).Total Quality Management process,-a systematic approach, Advances in Total Quality Management Series, 4, Carfax Publishing, Abingdon.

Kelada, J. N., Integrating Reengineering With Total Quality, Asq Pr., Wisconsin, 1996, 471 pages, ISBN-13: 978-0873893398.

Macchion, L., Moretto, A., Caniato, F., Caridi, M., Danese, P. and Vinelli, A.(2015). Production and Supply Network Strategie s within the Fashion Industry, International Journal of Production Economics, 163, 173-188.

Martinich, Joseph, S. (1997). Production and Operations Management, an Applied Modern Approach, New York: John Willey and Sons, Inc.

Morgan, L. R. and Birtwistle, G. (2009). An investigation of young fashion consumers' disposal habits. International Journal of Consumer Studies, 33(2), Blackwell Publishing, 190-198.

Ngambi, M.I T. and Nkemkiafu, A. G. (2015), The Impact of Total Quality Management on Firm's Organizational Performance, Amer ican Journal of Management, 15(4), 69-70.

Oakland, J. (2005). From Quality to Excellence in the 21st Century. Total Quality Management. 16 (8-9), 1053-1060.

Oakland, J., Total Quality Management: The Route to Improving Performance, Nichols Publishing Company; 2nd ed. Edition, Great Britain, 463 p., ISBN-13: 978-0893973865.

Porter, L.J., and Parker, A.J. (1993). Total Quality Management: The critical success factors. Total Quality Management. 4(1), 810-829.

Powell, T. C. (1995). Total Quality Management as Competitive Advantage: A Review and Empirical Study. Strategic Management Journal, 16, 15-37. https://www.jstor.org/stable/2486944. 
Qaiser, S. and Rizwana, G. (2015), Challenges to Successful Total Quality Management Implementation in Public Secondary Schoo Is: A Case Study of Kohat District, Pakistan, Journal of Education and Practice, 6(15), p.123.

Ross, Joel E (1993). Total Quality Management: Text, Cases and Readings, Boca Raton, F.L : St. Lucie Press. 2 Edition, USA F lorida.

Samat, N., Ramayah, T. and Saad, N. M. (2006). TQM practices, service quality, and mar ket orientation. Management Research News, 29 (11), 713-728. DOI 10.1108/01409170610716025.

Wilkinson, A. (1992). The other side of quality: 'soft' issues and the Human resource dimension. Total Quality Management. 3 (3), 323-329. 